\title{
Relative grazing impact of microzooplankton and mesozooplankton on a bloom of the toxic dinoflagellate Alexandrium minutum
}

\author{
Albert Calbet*, Dolors Vaqué, Jordi Felipe, Magda Vila, Maria Montserrat Sala, \\ Miquel Alcaraz, Marta Estrada
}

Institut de Ciències del Mar CMIMA (CSIC), Passeig Marítim de la Barceloneta 37-49, 08003 Barcelona, Spain

\begin{abstract}
Grazing can be a substantial loss factor for harmful algal blooms (HABs) and a possible cause of their termination. There is, however, a considerable gap in our knowledge of the relative grazing impact of the different components of the planktonic community on a red tide. In this study, we examine the importance of grazing control on a naturally occurring bloom of the toxic dinoflagellate Alexandrium minutum. We estimated the grazing impact of microzooplankton (by the dilution method) and copepods (by $24 \mathrm{~h}$ incubations with cultured populations of Acartia grani and Oithona davisae) on a bloom of $A$. minutum. Grazing by microzooplankton $\left(0.84 \mathrm{~d}^{-1}\right)$ was equal to and even exceeded $A$. minutum growth rates $\left(0.79 \mathrm{~d}^{-1}\right)$. On the other hand, copepod impact on the $A$. minutum population was not significant, although they were actively feeding on the dinoflagellate, which accounted for 78 and $86 \%$ of the daily carbon intake of $A$. grani and $O$. davisae, respectively. Even if these results were extended to the highest realistic copepod abundance attainable in the area, the grazing impact on highly concentrated HABs would not be sufficient to significantly reduce the algal concentrations. In summary, grazing by microzooplankton can represent an important factor for the regulation of HABs.
\end{abstract}

KEY WORDS: Harmful algal bloom - Alexandrium minutum • Microzooplankton · Mesozooplankton · Acartia grani . Oithona davisae · Grazing

Resale or republication not permitted without written consent of the publisher

Harmful algal blooms (HABs) are becoming a commonly reported phenomenon in coastal and (semi-) confined waters, although uncertainty remains as to the causes of their apparently increased occurrence are still unknown (Anderson 1989, Hallegraeff 1993). Even more complex than the possible causes seem to be the factors controlling the development of these phenomena. There are different mechanisms that may act to regulate both the proliferation and the decline of a red tide. Hydrodynamism and meteorological events can act as concentrating agents for HABs, but can also rapidly disperse the bloom, their influence being determined by the topography of the area and the intensity of the physical stress (Steidinger 1973, Garcés et al. 1999, Vila et al. 2001). Inorganic nutrients are needed in the growth of HABs, their depletion resulting in cell mortality or in the formation of resting cysts (Anderson \& Lindquist 1985). Interactions with other organisms are also important in determining the fate of algal populations. In this context, allelopathy, viruses, parasites and grazers are potential agents controlling red tides (Nagasaki et al. 1994, Zingone 1995, Coats et al. 1996, Turner \& Tester 1997, Guisande et al. 2002, Johansson \& Coats 2002). Amongst the biological factors influencing HABs, grazing pressure stands out as the most direct and widespread. Despite the importance of this trophic interaction, the role of grazing impact on HABs has been determined in relatively few studies (see review by Turner \& Tester 1997), and most of them estimated the impact of grazers by indirect methods (Nakamura et al. 1995, 1996, Matsuyama et al. 1999). The outcomes of these studies are diverse and highly species- and site-specific (Turner \& Tester 1997). In general, the effect of mesozooplankton grazing seems to be more relevant during the early stages of bloom formation, their influence being less decisive once the bloom is well established (Uye 1986). Microzooplankton grazing, on the other hand, has been shown to play a more active role in the decline of HABs (Nakamura et al. 1995, 1996, Matsuyama et al. 1999), although its impact has been seldom measured in situ (Gobler et al. 2002). There is, moreover, a clear lack of research comparing the effects of meso- and microzooplankton grazing impacts on the same HAB episode. The aim of this study was therefore to examine the importance of both micro- and mesozooplankton grazing as control agents for the proliferation of a naturally occurring HAB. 
Materials and methods. Community structure: Experiments were conducted during January 2002, coincident with a bloom of Alexandrium minutum in the harbour of Arenys de Mar (40 km north of Barcelona, NW Mediterranean). The microplanktonic community structure was monitored monthly as part of a HAB detection program. Once the initiation of the bloom was evident, the sampling frequency was increased to 2 to 3 samples $\mathrm{wk}^{-1}$. The standard method of sampling consisted of preserving $150 \mathrm{ml}$ water from the patch of dinoflagellates with Lugol's solution (1\% final concentration). Between 10 and $50 \mathrm{ml}$ of the preserved samples were settled in Utermöhl chambers for $24 \mathrm{~h}$ and counted under an inverted microscope. Copepod abundance was assessed on the day of the experiment (January 29), using a $36 \mathrm{~cm}$ diameter plankton net with $53 \mu \mathrm{m}$ mesh, hauled vertically from near the bottom to the surface. Samples were quickly preserved in buffered formalin ( $4 \%$ final concentration) for later analysis. In the laboratory, the species composition of the mesozooplanktonic community was estimated by counting and identifying all organisms in the sample.

Microzooplankton grazing impact: Microzooplankton grazing was assessed by the dilution method (Landry \& Hassett 1982). Water was collected from the experimental site and transported in carboys to the laboratory within $1 \mathrm{~h}$ of collection. Once in the laboratory, duplicate bottles $(500 \mathrm{ml})$ were filled with natural seawater $(100 \%)$, previously screened through $150 \mu \mathrm{m}$ mesh to remove mesozooplankton, and diluted with filtered $(0.2 \mu \mathrm{m})$ seawater to obtain dilution fractions of $1,0.75,0.5$ and 0.25 . Samples were incubated in a culture room under temperature conditions similar to those in situ $\left(15.5^{\circ} \mathrm{C}\right)$ for $24 \mathrm{~h}$ on a slow rotating (0.2 rpm) plankton wheel. Aliquots to assess Alexandrium minutum and ciliate abundance were collected at the beginning and at the end of the experiment and preserved with acidic Lugol (1\% final concentration). To correct for ciliate losses due to preservation, a factor of $30 \%$ was applied (E. Broglio, E. Saiz, A. Calbet, I. Trepat, M. Alcaraz unpubl.). We did not amend the incubations with nutrients to avoid possible adverse effects on grazers (Gifford 1988), and because the sampling area presents high enough nutrient levels to guarantee saturating phytoplankton growth conditions (M. Vila et al. unpubl.).

Counts of Alexandrium minutum and ciliates were carried out using an inverted microscope on $10 \mathrm{ml}$ Utermöhl settling chambers, after samples had settled for $24 \mathrm{~h}$. More than 400 cells of A. minutum and 50 to 200 ciliates were counted per sample. Growth and grazing rates on $A$. minutum were calculated from the regression equation between net growth rate for each dilution bottle and dilution factor. The intercept of the equation is an estimation of the gross growth without predators and the slope coefficient corresponds to the community grazing rate (Landry \& Hassett 1982).

To evaluate the extent of rotifer feeding impact on the bloom, Synchaeta triophthalma (the most abundant rotifer in the bloom) feeding rates on Alexandrium minutum were estimated with an incubation experiment using cultured organisms. The design consisted of 12 treatments, comprising 4 initial, 4 experimental and 4 control $75 \mathrm{ml}$ polystyrene culture flasks (Corning). All flasks were filled with a suspension of $A$. minutum at a concentration of 3000 cells ml ${ }^{-1}$. S. triophthalma was added to the experimental flasks at a concentration of 20 individuals $\mathrm{ml}^{-1}$. Both experimental and control treatments simulated natural abundances, of predator and prey in the bloom. The flasks were incubated for $24 \mathrm{~h}$ on a rotating plankton wheel $(0.2 \mathrm{rpm})$ at in situ temperature $\left(15.5^{\circ} \mathrm{C}\right)$ and under a $12 \mathrm{~h}$ day/night light cycle. At the beginning and end of the incubations, the total flask contents were preserved with Lugol's solution ( $2 \%$ final concentration). As for the microplankton community structure monitoring, $10 \mathrm{ml}$ of the preserved samples were settled in Utermöhl chambers for $24 \mathrm{~h}$ and counted under an inverted microscope.

Mesozooplankton grazing impact: Mesozooplankton grazing impact was estimated by copepod feeding experiments on the natural microplankton. The dominant organisms in the mesozooplankton community of the Arenys de Mar harbour were the copepods Acartia grani and Oithona sp. However, mesozooplankton were generally very scarce, precluding the use of wild animals for the experiments. Therefore, the experiments were conducted with cultured populations of $A$. grani (943.1 \pm 10.19 [SE] $\mu \mathrm{m}$ in length), and $O$. davisae $(327.9 \pm 2.32[\mathrm{SE}] \mu \mathrm{m}$ in length). These 2 species were originally collected from the Barcelona harbour and had been kept under controlled conditions for more than 2 yr. Around 100 O. davisae (males and females) or 25 A. grani (females) were incubated in triplicate with the natural seston community of the bloom for $24 \mathrm{~h}$ in $75 \mathrm{ml}$ polystyrene culture flasks (Corning). Incubations took place on a rotating ( $0.2 \mathrm{rpm})$ plankton wheel under a $12 \mathrm{~h}$ day/night light cycle at $15.5^{\circ} \mathrm{C}$. The copepod concentration used in the experiments may seem too high for extrapolation of the resulting grazing rates to the natural community. However, considering the extremely high microplankton concentrations $(3 \times$ $10^{3}$ cells ml ${ }^{-1}$ Alexandrium minutum, $23.4 \pm 0.35$ [SE] $\mu \mathrm{m}$ in diameter), an equally high abundance of predators was needed to detect the cell reduction by grazing effect. The experimental copepod:prey ratio allowed values close to the satiation of feeding (see 'Results') with a decrease at the end of the incubation of 40 and $20 \%$ of A. minutum concentration for A. grani and $O$. davisae, respectively. For the other microplanktonic 
groups, reduction of abundance in the experimental flasks with respect to controls ranged from 30 to $57 \%$ and 9 to $21 \%$ for $A$. grani and $O$. davisae incubations, respectively. Copepod mortality was $\leq 1 \%$ for the 2 species studied. Initial and final samples were preserved with Lugol's solution (1\% final concentration). Aliquots of $12 \mathrm{ml}$ were settled in Utermöhl chambers for $48 \mathrm{~h}$ and counted under an inverted microscope. Ingestion and clearance rates on microplankton were calculated from cell disappearance using the equations of Frost (1972). Video images of 30 random cells of each dominant group were digitized with a Power Macintosh computer, equipped with a frame grabber and NIH Image analysis software (National Institute of Health, Bethesda, Maryland). The contour of the organisms was outlined, the area measured, and the length and width of the cell automatically estimated, assuming an ellipsoidal shape. For chain forming diatoms, each cell was counted as an individual organism.

Microplankton biovolumes were converted to cell

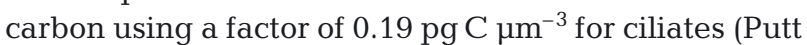
\& Stoecker 1989) and the equations provided by Menden-Deuer \& Lessard (2000) for the other components of the community. Zooplankton carbon contents were obtained from the length-weight relationships of Uye (1982) and Uye \& Sano (1998) for Acartia grani and Oithona davisae, respectively. Rotifer abundance was converted to carbon using a value of $18.12 \mathrm{ng} \mathrm{C}$ rotifer $^{-1}$ (Egloff 1988).

Results and discussion. The natural evolution of the Alexandrium minutum bloom is shown in Fig. 1. A. minutum cells were recorded at low levels throughout the year in the Arenys de Mar harbour, but at the end of December the organisms began to increase their basal concentration in a patch at the northern part of the harbour. It was not until the end of January that they reached maximum concentrations in the sampled station and thereafter invaded the whole harbour. On the day of the experiment (January 29, 2002) the bloom was in the maintenance phase, although showing a decline in cell numbers, with abundance of $A$. minutum around 2000 to 3000 cells ml ${ }^{-1}$. The composition of the microplankton community corresponding to the date of the experiments is shown in Table 1. At first glance, the data reveals a community numerically dominated by cells of Skeletonema sp. and A. minutum. However, when these values are expressed as carbon, A. minutum appears as the major contributor to microplankton biomass ( $80 \%$ of total biomass). Other important components of the community were the dinoflagellate Prorocentrum micans and centric diatoms of the genus Thalassiosira. Ciliates (mostly Mesodinium spp., Strombidium spp., and tintinnida) and rotifers Synchaeta triophthalma were the dominant microplanktonic grazers. In contrast to the re-

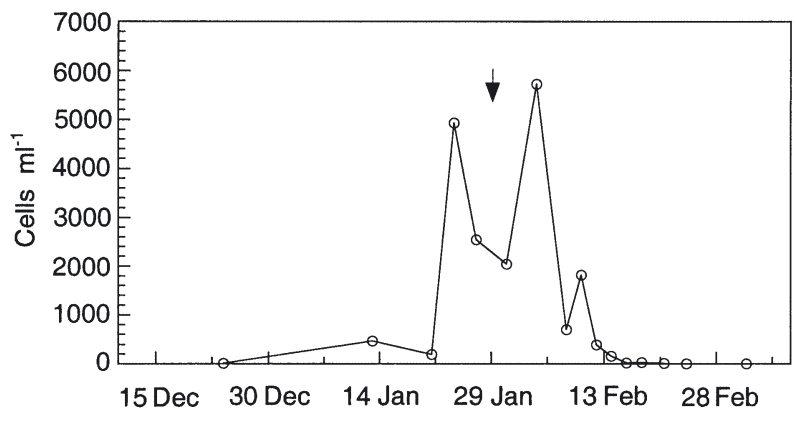

Fig. 1. Alexandrium minutum. Temporal pattern of abundance in the Arenys de Mar harbour from December 2001 to March 2002. Only the months in which the dinoflagellate was detected are shown. Arrow indicates day of the experiment (January 29)

markable abundance of micrograzers, larger predators, such as copepods, were very scarce, showing an average abundance in the harbour of 51 ind. $\mathrm{m}^{-3}$ for Oithona sp and 23 ind. $\mathrm{m}^{-3}$ for Acartia grani. No significant differences were found in the abundance of copepods in different locations of the harbour.

The results of the dilution experiment were evidence of an actively growing population of Alexandrium minutum, with growth rates $\left(0.79 \mathrm{~d}^{-1}\right)$ comparable to those found during the exponential phase of previous blooms of this species in the studied area $\left(0.9 \mathrm{~d}^{-1}\right.$, Garcés et al. 1998). The grazing by microzooplankton on A. minutum $\left(0.84 \mathrm{~d}^{-1}\right)$ accounted for, and even exceeded, the growth rates of the dinoflagellates (Fig. 2). No clear effect of dilution treatments on the growth rates of potential protozoan grazers was evident during the experiments (ciliates $\mathrm{r}^{2}=0.06$ ), and no satiation of the feeding was apparent (Gallegos 1989, Redden et al. 2002). According to the dilution experiment, the A. minutum bloom was in a slight recession phase, with an $11.3 \% \mathrm{~d}^{-1}$ decline in the population. This result is consistent with the temporal evolution of the bloom, because the experiments were conducted during a decline in the abundance of cells (around $5 \% \mathrm{~d}^{-1}$ from January 27 to 31 , or $16 \%$ from January 24 to 31 ).

Table 1. Microplanktonic community composition in terms of abundance and biomass, both expressed as mean $\pm \mathrm{SE}$

\begin{tabular}{|lcc|}
\hline Organism & Cells ml & $\mu \mathrm{g} \mathrm{C} \mathrm{ml}^{-1}$ \\
\hline Alexandrium minutum & $2887 \pm 235$ & $3.00 \pm 0.25$ \\
Prorocentrum micans & $117 \pm 7$ & $0.42 \pm 0.03$ \\
Skeletonema sp. & $8170^{\mathrm{a}} \pm 667$ & $0.20 \pm 0.02$ \\
Thalassiosira sp. & $35 \pm 21$ & $0.01 \pm 0.01$ \\
Ciliates & $53 \pm 10$ & $0.08 \pm 0.01$ \\
Synchaeta triophthalma & 21 & 0.38 \\
aEach cell within the chain was considered as an indi- \\
vidual organism
\end{tabular}




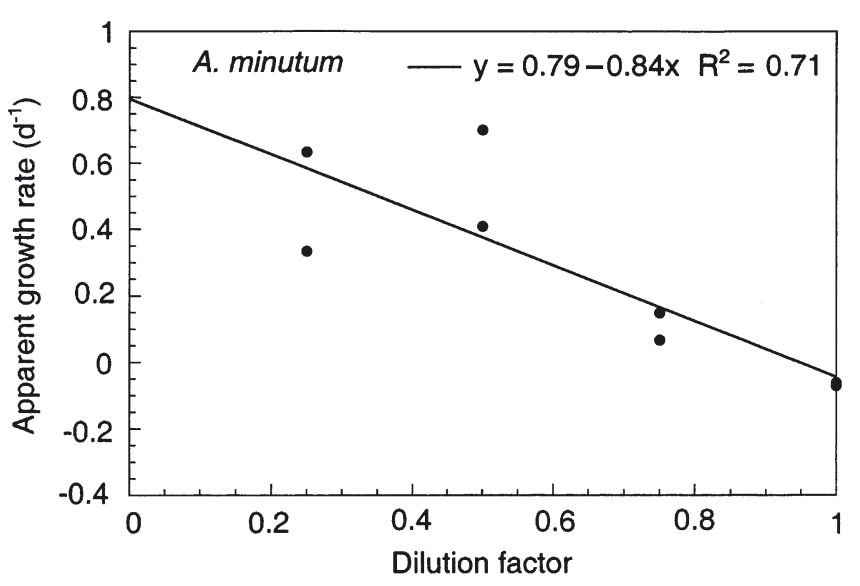

Fig. 2. Alexandrium minutum. Apparent growth rate as a function of the dilution factor in the dilution experiment

The ingestion rates of the 2 copepod species tested are shown in Fig. 3A,B. Acartia grani ingestion rates were significant $(t$-test, $\mathrm{p}<0.05)$ for all microplanktonic groups, except ciliates. Oithona davisae, on the other hand, only presented significant $(\mathrm{p}<0.05)$ feeding rates on Alexandrium minutum and Prorocentrum micans. Ingestion rates on Skeletonema sp., although very high, were not significant due to strong variability within control bottles. Since feeding on ciliates was low and not significant for either of the copepod species, no attempt was made to correct for contribution of ciliate feeding on phytoplankton to the experiments (Nejstgaard et al. 2001). A. grani ingestion and clearance rates (Fig. 3C,D) were roughly 1 order of magnitude higher than those of $O$. davisae. The majority of the feeding was centered on the most abundant cells, A. minutum and Skeletonema sp. These feeding patterns do not seem to be the result of a selection for any specific group, but the consequence of the relative abundance of the different prey, as is evident from the homogeneity in clearance rates (Fig. 3C,D). Weight specific ingestion rates were high for both species, with values of $250 \%$ of the body carbon ingested per day for O. davisae (Fig. 3F), and $125 \%$ for A. grani (Fig. 3E). Consistent with the cell-based ingestion rates, most of the carbon ration resulted from the ingestion of dinoflagellates. Despite the considerable ingestion rates shown by the 2 species of copepods, their impact on the evolution of the bloom was not significant. The feeding of $A$. grani and $O$. davisae on $A$. minutum, estimated by multiplying the feeding rates obtained from experiments by the natural abundance of each copepod species, only resulted in a daily reduction of 0.007 and $0.003 \%$ of the standing stock, respectively.

The tight control exerted by microzooplankton grazing on the net growth rate of Alexandrium minutum is the most evident result of the present study. This contrasts with the minor effect of mesozooplankton (copepod) grazing. Even when the feeding rates found in our study are extrapolated to the maximum attainable abundance of copepods observed in similar areas (15 copepods $\mathrm{l}^{-1}, \mathrm{M}$. Alcaraz unpubl.), their grazing on A. minutum does not represent a significant impact on the evolution of an established $A$. minutum bloom. For example, a grazing impact equivalent to the daily A. minutum growth would require 848 Acartia grani or 6193 Oithona davisae $\mathrm{l}^{-1}$, which are unrealistic abundances. In contrast, microzooplankton can be numerically more important and have shorter generation times, thus enabling their grazing rates to impact on the growth rates of the dinoflagellates. Furthermore, the short microzooplankton generation times are a key factor in allowing fast proliferation of toxin-resistant species which benefit from the bloom. In our sampling, ciliates and rotifers were very abundant within the dinoflagellate patch (Table 1). Synchaeta spp. are active grazers on dinoflagellates, not presenting satiation of feeding within the range of prey concentration found in the present study (Egloff 1988). Our results show that Synchaeta triophthalma feeding on a culture of A. minutum at concentrations similar to in situ presented ingestion rates ranging from 44 to 80 cells ind..$^{-1} \mathrm{~d}^{-1}$ (average $58.4 \pm 8.7$ [SE]). Ingestion rates for tintinida feeding on a $23.4 \mu \mathrm{m}$ diameter cell (equivalent to $A$. minutum) range from 40 to 50 cells ind..$^{-1} \mathrm{~d}^{-1}$ (Kamiyama \& Arima 2001 ). Considering that only $\sim 30 \%$ of ciliates were able to feed on A. minutum (mostly tintinnids, and Didinium $\mathrm{sp}$.), the combined feeding rates of both groups (54 to $85 \%$ of $A$. minutum standing stock) is consistent with the values of grazing obtained from the dilution experiments. Obviously, the former estimation of grazing impact is just a rough approximation, since clearance and ingestion rates are highly specific and dependent on prey size and concentration; however, it allows us to establish the fact that certain groups within the microzooplankton are able to produce most of the feeding impact detected. The results obtained here consolidate the robustness of the dilution method as an estimator of microzooplanktonic grazing. Further support of the reliability of the method is found in the close relationship observed between grazing estimates and temporal evolution of the dinoflagellate bloom at the sampled station. The slight difference between A. minutum growth and grazing rates, resulting in a decline of the population of $11.3 \% \mathrm{~d}^{-1}$, is enough to explain the temporal evolution of the natural abundance of toxic dinoflagellates during the period of the experiments. However, patchiness at these high concentrations is sometimes important and could not be discarded as an effect masking the real abundance of $A$. minutum in the area, which makes relationships — such as the decline 

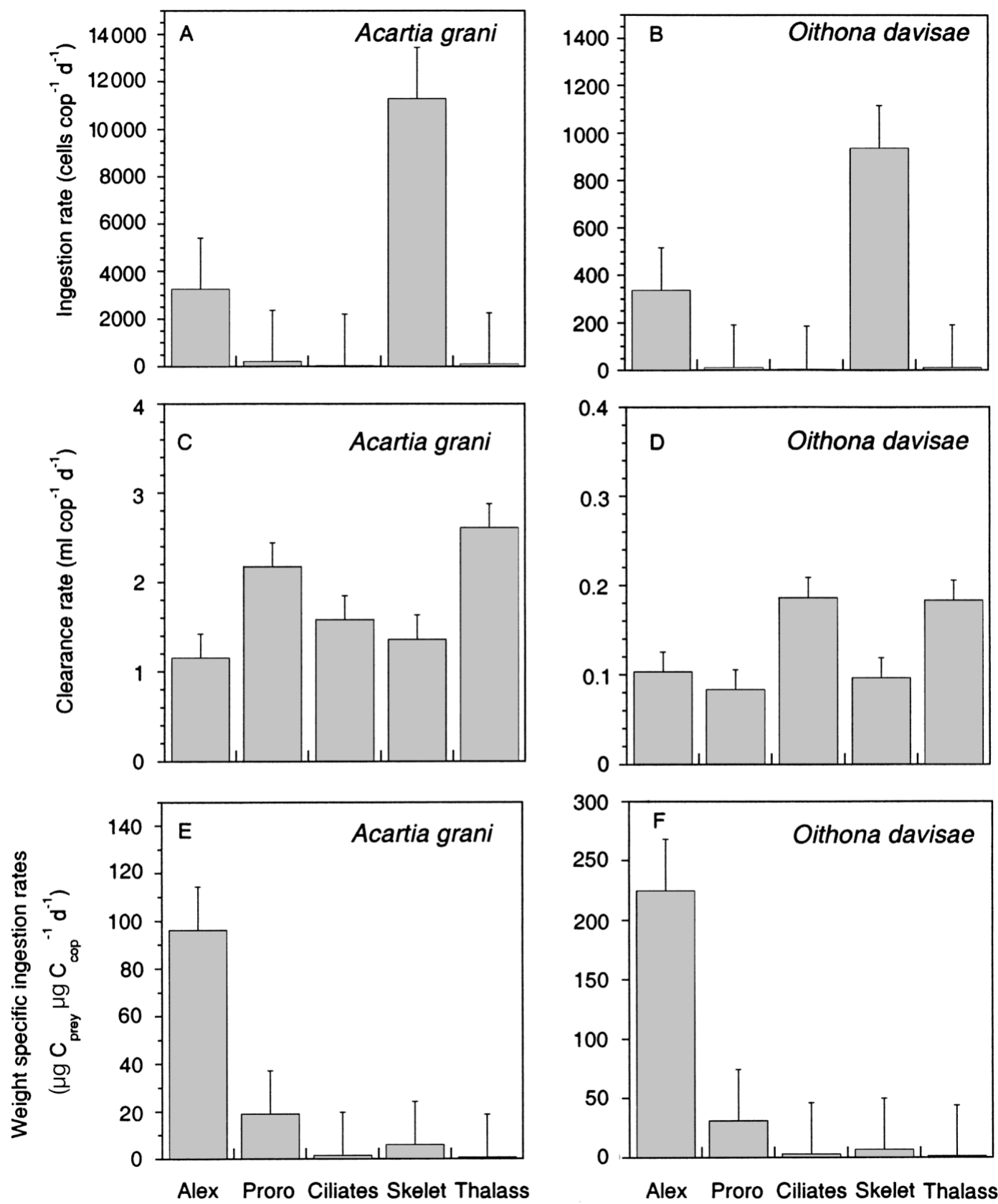

Fig. 3. Acartia grani and Oithona davisae. $(\mathrm{A}, \mathrm{B})$ Ingestion rates (cells copepod $\left.{ }^{-1} \mathrm{~d}^{-1}\right),(\mathrm{C}, \mathrm{D})$ clearance rates $\left(\mathrm{ml} \mathrm{copepod}^{-1} \mathrm{~d}^{-1}\right)$ and $(\mathrm{E}, \mathrm{F})$ carbon based ingestion rates $\left(\mu \mathrm{g} \mathrm{C}_{\text {prey }} \mu \mathrm{g} \mathrm{C}_{\mathrm{cop}}{ }^{-1} \mathrm{~d}^{-1}\right)$ on the different components of the microplanktonic community. Alex $=$ Alexandrium minutum, Proro = Prorocentrum micans, Skelet = Skeletonema sp., Thalass = Thalassiosira sp., cop = copepod. Error bars represent SE.

of the bloom and the imbalance between dinoflagellate growth and mortality - speculative to some extent. Nevertheless, there is no doubt about the significance of microzooplankton grazing in shaping dinoflagellate net growth, which reinforces recent reports on the relative importance of microzooplankton over large metazoans as predators in highly productive environments (Calbet 2001, Strom et al. 2001, Calbet \& Landry 2003).
Although active grazing by microzooplankton in marine communities is a common phenomenon (Strom et al. 2001 and references therein), studies reporting such tight coupling between phytoplankton growth and grazing under harmful algal bloom conditions are scarce (Buskey et al. 2001, Jeong et al. 2002). This coupling, as suggested by Strom et al. (2001), may be a result of the high potential growth and ingestion rates 
of protist grazers. We extend this potential capability to other groups, such as rotifers (Mallin et al. 1995, the present study), which have been either often ignored or simply inadequately sampled in natural community grazing experiments; heterotrophic dinoflagellates (Nakamura et al. 1992, 1995, Jeong \& Latz 1994), and meroplankton larvae (Turner \& Anderson 1983) being among the most frequent.

It seems, therefore, that microzooplankters may be important agents in controlling HABs, whereas mesozooplankton appears, in general, to be unable to prevent the proliferation of a well-established HAB (see Turner \& Tester 1997 for references). It is more probable that the mesozooplankton impact is significant in the initial phases of the bloom, either by feeding directly on the harmful algae or by reducing competition by selective feeding on competitors, parasites or other grazers of the algae (Uye 1986, Guisande et al. 2002, Johansson \& Coats 2002). Nevertheless, it is evident that copepods actively feed on Alexandrium minutum, which apparently has no feeding deterrent effect despite its toxicity (presence of Isomers GTX4 and GTX1 of PSP toxins, analysed by HPLC with postcolumn oxidation and fluorescence detection, K. Van Lenning, pers. comm.). This view is consistent with previous studies (da Costa \& Fernandez 2002, Guisande et al. 2002) showing that copepod feeding is inhibited only after several days of continuously ingesting A. minutum. The copepods we used in the experiments came from cultures and had never been exposed to any toxic dinoflagellate. It is probable that conducting the same experiments with the natural copepod community of the harbour would have resulted in much lower feeding rates. The long term feeding inhibitory effects could explain the low abundance of copepods in the Arenys de Mar harbour, which, according to parallel records in other harbours nearby, should show a peak of biomass at the time of the experiments (M. Alcaraz unpubl.). This harmful effect on copepods may be the result of direct ingestion of toxic dinoflagellates and of protozoa or small metazoa, the latter serving as vectors for the toxins. In a more favourable scenario, with other species at play, protozoans could act as detoxicating agents, allowing a safer carbon transfer from the toxic algae to higher trophic levels (Jeong et al. 2001).

In the present study, we do not present direct evidence of a bloom termination by microzooplankton grazing. There are other agents, not considered here, such as viruses, parasites, nutrient availability or climatic forcing that could have participated in ending the bloom. Most probably, there is no single mechanism involved in the termination of HABs. Moreover, our conclusions based on single day experiments in a particular bloom do not allow generalization to other areas. However, our study presents evidence of a tight coupling between microzooplankton grazing and a HAB forming dinoflagellate growth rate, and depicts a potentially important role for micrograzers in shaping the extent of toxic algae proliferations.

Acknowledgements. Financial support was provided by the European Union projects BIOHAB (EVK3-1999-00015) and STRATEGY (EVK3-2001-00046), the Spanish Ministry of Science and Technology project ZooTransfer (REN2001-1693), and the Agència Catalana de l'Aigua. A.C. was funded by a 'Ramón y Cajal' research contract from the Spanish Ministry of Science and Technology. We are indebted to Isabel Fernández for analysing the samples of microplankton corresponding to the copepod feeding experiments. Four anonymous reviewers considerably improved the manuscript with thoughtful comments and suggestions.

\section{LITERATURE CITED}

Anderson DM (1989) Toxic algal blooms and red tides: A global perspective. In: Okaichi T, Anderson DM, Nemoto $\mathrm{T}$ (eds) Red tides: biology, environmental science and toxicology. Elsevier, New York, p 11-16

Anderson DM, Lindquist NL (1985) Time-course measurements of phosphorus depletion and cyst formation in the dinoflagellate Gonyaulax tamarensis Lebour. J Exp Mar Biol Ecol 86:1-13

Buskey EJ, Liu H, Collumb C, Bersano JGF (2001) The decline and recovery of a persistent Texas brown tide algal bloom in the Laguna Madre (Texas, USA). Estuaries $24: 337-346$

Calbet A (2001) Mesozooplankton grazing impact on primary production: a global comparative analysis. Limnol Oceanogr 46:1824-1830

Calbet A, Landry MR (2003) Phytoplankton growth, microzooplankton grazing and carbon cycling in the upper oceans. Limnol Oceanogr (in press)

Coats DW, Adam EJ, Gallegos CL, Hedrick S (1996) Parasitism of photosynthetic dinoflagellates in a shallow sub-estuary of Chesapeake Bay, USA. Aquat Microb Ecol $11: 1-9$

da Costa RM, Fernández F (2002) Feeding and survival rates of the copepods Euterpina acutifrons Dana and Acartia grani Sars on the dinoflagellates Alexandrium minutum Balech and Gyrodinium corsicum Paulmier and the Chryptophyta Rhodomonas baltica Karsten. J Exp Mar Biol Ecol 273:141-142

Egloff DA (1988) Food and growth relations of the marine microzooplankter, Synchaeta cecilia (Rotifera). Hydrobiologia 157:129-141

Frost BW (1972) Effects of size and concentration of food particles on the feeding behavior of the marine planktonic copepod Calanus pacificus. Limnol Oceanogr 17:805-815

Gallegos CL (1989) Microzooplanton grazing on phytoplankton in the Rhode River, Maryland: nonlinear feeding kinetics. Mar Ecol Prog Ser 57:23-33

Garcés E, Delgado M, Vila M, Camp J (1998) An Alexandrium minutum bloom: in situ growth or accumulation? In: Reguera B, Blanco J, Fernández ML, Wyatt $\mathrm{T}$ (eds) Harmful algae. Xunta de Galicia and Intergovernmental Oceanographic Commission of UNESCO, Vigo, p 167-170 Garcés E, Masó M, Camp J (1999) A recurrent and localized 
dinoflagellate bloom in a Mediterranean beach. J Plankton Res 21:2373-2391

Gifford DJ (1988) Impact of grazing by microzooplankton in the Northwest Arm of Halifax Harbour, Nova Scotia. Mar Ecol Prog Ser 47:249-258

Gobler CJ, Renaghan MJ, Buck NJ (2002) Impacts of nutrients and grazing mortality on the abundance of Aureococcus anophagefferens during a New York brown tide bloom. Limnol Oceanogr 47:129-141

Guisande C, Frangopulos M, Maneiro I, Vergara AR, Riveiro I (2002) Ecological advantages of toxin production by the dinoflagellate Alexandrium minutum under phosphorus limitation. Mar Ecol Prog Ser 225:169-176

Hallegraeff GM (1993) A review of harmful algal blooms and their apparent global increase. Phycologia 32:79-99

Jeong HJ, Latz MI (1994) Growth and grazing rates of the heterotrophic dinoflagellate Protoperidinium spp. on red tide dinoflagellates. Mar Ecol Prog Ser 106:173-185

Jeong HJ, Kang HJ, Shim JH, Park JK, Kim JS, Song JY, Choi HJ (2001) Interactions among the toxic dinoflagellate Amphidinium carterae, the heterotrophic dinoflagellate Oxyrrhis marina, and the calanoid copepods Acartia spp. Mar Ecol Prog Ser 218:77-86

Jeong HJ, Yoon JY, Kim JS, Yoo YD, Seong KA (2002) Growth and grazing rates of the prostomatid ciliate Tiarina fusus on red-tide and toxic algae. Aquat Microb Ecol 28:289-297

Johansson M, Coats DW (2002) Ciliate grazing on the parasite Amoebophrya sp. decreases infection of the red-tide dinoflagellate Akashiwo sanguinea. Aquat Microb Ecol 28:69-78

Kamiyama T, Arima S (2001) Feeding characteristics of 2 tintinnid ciliates species on phytoplankton including harmful species: effects of prey size on ingestion rates and selectivity. J Exp Mar Biol Ecol 257:281-296

Landry MR, Hassett RP (1982) Estimating the grazing impact of marine micro-zooplankton. Mar Biol 67:283-288

Mallin MM, Burkholder JM, Larsen LM, Glasgow HBJ (1995) Response of 2 zooplankton grazers to an ichthyotoxic estuarine dinoflagellate. J Plankton Res 17:351-363

Matsuyama Y, Miyamoto M, Kotani Y (1999) Grazing impacts of the heterotrophic dinoflagellate Polykrikos kofoidii on a bloom of Gymnodinium catenatum. Aquat Microb Ecol 17:91-98

Menden-Deuer S, Lessard EJ (2000) Carbon to volume relationships for dinoflagellates, diatoms, and other protist plankton. Limnol Oceanogr 45:569-579

Nagasaki K, Ando M, Itakura S, Imai I, Ishida Y (1994) Viral mortality in the final stage of Heterosigma akashiwo

Editorial responsibility: Otto Kinne (Editor),

Oldendorf/Luhe, Germany
(Raphidophyceae) red tide. J Plankton Res 16:1595-1599

Nakamura Y, Yamazaki Y, Hiromi J (1992) Growth and grazing of the heterotrophic dinoflagellate, Gyrodinium dominans, feeding on a red tide flagellate, Chattonella antiqua. Mar Ecol Prog Ser 82:275-279

Nakamura Y, Suzuki SY, Hiromi J (1995) Growth and grazing of a naked heterotrophic dinoflagellate, Gyrodinium dominans. Aquat Microb Ecol 9:157-164

Nakamura Y, Suzuki S, Hiromi J (1996) Development and collapse of a Gymnodinium mikimotoi red tide in the Seto Inland Sea. Aquat Microb Ecol 10:131-137

Putt M, Stoecker DK (1989) An experimentally determined carbon: volume ratio for marine 'oligotrichous' ciliates from estuarine and coastal waters. Limnol Oceanogr 34: 1097-1103

Redden AM, Sanderson BG, Rissik D (2002) Extending the analysis of the dilution method to obtain the phytoplankton concentration at which microzooplankton grazing becomes saturated. Mar Ecol Prog Ser 226:27-33

Steidinger KA (1973) Phytoplankton ecology: a conceptual review based on eastern Gulf of Mexico research. CRC Rev Microb 3:49-68

Strom SL, Brainard MA, Holmes JL, Olson MB (2001) Phytoplankton blooms are strongly impacted by microzooplankton grazing in coastal North Pacific waters. Mar Biol 138:355-368

Turner JT, Anderson DM (1983) Zooplankton grazing during dinoflagellate blooms in a Cape Cod embayment, with observations of predation upon tintinnids by copepods. PSZN I: Mar Ecol 4:358-374

Turner JT, Tester PA (1997) Toxic marine phytoplankton, zooplankton grazers, and pelagic food webs. Limnol Oceanogr 42:1203-1214

Uye S (1982) Length-weight relationships of important zooplankton from the Inland Sea of Japan. J Oceanogr Soc Jpn 38:149-158

Uye S (1986) Impact of copepod grazing on the red-tide flagellate Chattonella antigua. Mar Biol 92:35-43

Uye S, Sano K (1998) Seasonal variations in biomass, growth rate and production rate of the small cyclopoid copepod Oithona davisae in a temperate eutrophic inlet. Mar Ecol Prog Ser 163:37-44

Vila M, Garcés E, Masó M, Camp J (2001) Is the distribution of the toxic dinoflagellate Alexandrium catenella expanding along the NW Mediterranean coast? Mar Ecol Prog Ser 222:73-83

Zingone A (1995) The role of viruses in the dynamics of phytoplankton blooms. G Bot It 129:415-423

Submitted: February 18, 2003; Accepted: June 13, 2003

Proofs received from author(s): September 3, 2003 